\title{
Systemic provocation in doxycycline induced fixed drug eruption: a case report
}

\author{
Anik Murwaningsih ${ }^{1 *}$, Rosmarini Estri Sih Hananti ${ }^{2}$, Niken Indrastuti ${ }^{2}$ \\ 'Sentra Medika Hospital, Bogor, West Java, '2Department of Dermato-Venereology, \\ Faculty of Medicine, Universitas Gadjah Mada/Dr. Sardjito General Hospital, Yogyakarta, \\ Indonesia
}

\begin{abstract}
Fixed drug eruption (FDE) is recurrent lesions that upon repeated uptake of causative drug, always appears at the same skin and mucosal site. Determination of causal relationship in drug allergy is very important. In this case report, cases of doxycycline-induced FDE was reported. The subject of the research was a 29-year-old male, referred by dermatologist, with history of reccurent FDE. Physical examination revealed an oval well demarcated patch hyperpigmentation. Patch test was perfomed on previous involved and uninvolved site. The result of the patch test was irrelevant. Retesting patch test gave similar result. Systemic provocation test or drug provocation test (DPT) with doxcycline were done with suspected drug under ambulatory survelance and gave positive result. In this case, the DPT succeeded to identify doxycycline as the causal agent of FDE. The work-up of a suspected drug hypersensitivity includes a detailed clinical history, physical examination, skin tests, and provocation tests. The DPT is recommended to confirm drug's hypersensitivity reactions. Systemic provocation test is considered as the gold standard for diagnosing FDE.
\end{abstract}

\section{ABSTRAK}

Erupsi obat tetap merupakan lesi berulang akibat pemberian obat penyebab, selalu terjadi pada mukosa dan kulit yang sama. Penentuan penyebab terjadinya alergi obat sangat penting. Dalam laporan kasus ini dilaporkan erupsi obat tetap yang diinduksi oleh doksisiklin. Pria berumur 29 tahun, dirujuk oleh dermatologis, dengan riwayat erupsi obat tetap berulang. Hasil pemeriksaan fisik menunjukkan sebuah bercak hiperpigmentasi lonjong yang jelas. Uji tempel dilakukan pada tempat yang terkena dan tidak terkenan sebelumnya. Uji tempel tidak memberikan hasil yang sesuai. Uji tempel dilakukan lagi dengan hasil yang sama dengan uji sebelumnya. Uji provokasi obat dengan doksisiklin dilakukan dengan obat yang diduga sebagai penyebab dengan pemantauan dengan hasil positif. Dalam kasus ini uji provokasi obat berhasil mengidentifikasi doksisiklin sebagai penyebab erupsi obat tetap. Rangkaian tindakan untuk membuktikan obat yang diduga menimbulkan hipersensitivitas meliputi memperoleh riwayat klinik secara mendalam, pemeriksaan fisik, uji kulit dan uji provokasi. Uji provokasi obat direkomendasikan untuk membuktikan adanya reaksi hipersensitivitas. Uji provokasi sistemik dipandang sebagai baku emas dalam diagnsosi erupsi obat tetap.

Keywords: fixed drug eruption - doxycycline - causal relationship - patch test - systemic provocation test.

\footnotetext{
* corresponding author: anikm_drdv@yahoo.com
} 


\section{INTRODUCTION}

Fixed drug eruption (FDE) is a common subset of cutaneous reactions that arises due to various drugs. The term of FDE was introduced by Brocq in 1894, although this phenomenon was initially described by Bourns in 1889 . Fixed drug eruption is defined as recurrent lesions that upon repeated uptake of the causative drug, always appear at the same skin or mucosal sites. In its classical form FDE typically presents round or oval, sharply demarcated, red to livid, slightly elevated plaques ranging form several millimeters to more than $10 \mathrm{~cm}$ in diameter. After intake of the offending drug, FDE appears within minute up to several hours (about 30 minutes to 8 hours). Its appearance is preceded and accompanied by sensations of itching or burning. Desquamation takes place as the eruption fades, and there remains in the affected areas, a pigmentation of variable shade and duration. ${ }^{1,2}$

In the United State, the prevalence of FDE is reported to range from $2-5 \%$ for inpatients and greater than $1 \%$ for outpatients. The FDE may account for as much as $16-21 \%$ of all cutaneous drug eruptions. ${ }^{3}$ Moreover, Patel \& Marfatia ${ }^{4}$ reported that $\mathrm{FDE}(30.5 \%)$ as the most common eruption in cutaneous adverse drug reaction in India from 1997-20006. Most studies reported the FDE to be the second or third most common skin manifestation of adverse drug events. ${ }^{5}$ Some drugs have been reported to cause FDE such as cotrimoxazole, tetracycline, metamizole, phenylbutazone, paracetamol, metronidazole, tinidazole, ampicillin, erythromycin, griseofulvin, phenobarbitone, pyrantel pamoate, clindamycin, albendazole, dapsone, phenolphthalein, phenacetin, minocycline, panmycin, sulfonamide, sulfasalazine, benzodiazepines, chlordiazepoxide and fluconazole..$^{6-8}$

Determination of causal relationship in drug allergy is very important. Not evaluating this relationship can lead to fear of multiple drug allergies and unnecessary avoidance of appropriate medications, with reliance on more expensive, or less effective, alternatives without a rational basis, thus laying economic burden on public health care system. ${ }^{9,10}$ Skin testing, especially the patch test, is a useful screening method to find causal relationship of cutaneous adverse drug reactions (CADRs). ${ }^{11}$ In case of FDE, patch testing at the site of previous lesion yields a positive response in up to $43 \%$ of patients. ${ }^{12}$ Drug provocation test should be carried out if the skin test is negative or dubious to confirm the association. ${ }^{11}$

Doxycycline is a tetracycline antibiotic used to treat a variety of infections. Doxycycline is frequently used to treat Lyme disease, chronic prostatitis, sinusitis, pelvic inflammatory disease, acne, rosacea, and rickettsial infections. ${ }^{13-15}$ The side effects of doxycycline are similar to those of other members of the tetracycline antibiotic group including phototoxicity, stomach or bowel upsets and allergic reactions. ${ }^{16}$ Fixed drug eruption due to doxycycline has been reported by some authors. ${ }^{17-19}$ However, the doxycyclineinduced FDE is not often reported on Indonesian patients. In this report, a case of doxycyclineinduced FDE is reported. This report highlights discussion on systemic provocation test or DPT, as diagnostic methods to confirm drug hypersensitivity in the FDE.

\section{CASE REPORT}

A 29-year-old male, initial AI, unemployed, from Kuningan, Jakarta (Medical Record: 00.33.96.92) was referred from dermatologist to Dermatovenereology Outpatient Department, Dr. Sardjito General Hospital, Yogyakarta at July $10^{\text {th }}$, 2009 to perform patch test due to FDE on his left shoulder.

According to his history, one month earlier the patient received doxycycline from dermatologist due to his acne. Less than 10 hours after taking 
$100 \mathrm{mg}$ doxycycline tablet, slightly reddish erythematous plaque appeared on his left shoulder, which was preceded and accompanied by sensations of itching and burning. The reaction resolved with cessation of the drug. Hyperpigmentation remained in the affected areas. In previous history, since eight years ago the same eruption appeared at the same site every time the patient received any drug for his fever, the patient could not mention the kind of medication. There were neither previous history nor family history of asthma, rhinitis alergica, eczema, nor drug allergy. The patient could not recall any history of taking the doxycycline or tetracycline before. On physical examination, vital sign was within normal limit. Dermatological examination revealed an oval $10 \times 10 \mathrm{~cm}^{2}$ well demarcated patch hyperpigmen-tation on his left shoulder at the similar site with previous lesion.

Patient was diagnosed with FDE due to doxycycline. Patch test was performed on July $13^{\text {th }}, 2008$, five weeks after the series resolution of drug eruption, to confirm the etiology of this FDE. The patient received patch tests, on his previously involved site, with the ingredients of doxycycline $10 \%$ and minocycline $10 \%$ from Cutaneous Adverse Drug Reaction (CADR) Series from Chemotechnique ${ }^{\circledR}$ and doxycycline 30,40 , and $60 \%$, from commercialized drug form, both in petrolatum and distilled water. Patch test was also using 29 allergens of the CADR Series CAD 100 on normal back skin. The result of patch test was negative or irrelevant with patient's history. Retesting of patch test was suggested to be performed.

Retesting of patch test was performed on the previously involved site 10 days later using doxycycline $10 \%$ and minocycline $10 \%$ from
CADR Series CAD 100 and doxycycline 30, 40 , and $60 \%$, from commercialized drug form, which was diluted in both petrolatum and distilled water. The result was almost similar with previous patch test. The second patch test with the alleged culprits was deemed negative despite the appearance of two papules eritema which in the day four tended to form pustule in its centers at the site of application of doxycycline $60 \%$. An oral DPT was suggested. After giving written and oral informed consent about DPT, the patient underwent reanamnese. There were no uncontrolled systemic diseases, uncontrolled asthma, or any history FDE with generalized bullous reaction. Patient did not ingest or apply the causative drugs, antihistamines, immunosuppresives and or topical or systemic corticosteroid for at least four week before. Patient was asked not to take any drug during DPT. On the day-1 patient received lactose containing placebo, then continued with drug tested in sequence of increasing dose at home under ambulatory surveillance.

The drug challenge was started with $1 / 8$ dose. The dose was doubled every 12 hours until the regular dose was reached. If any sign appeared, the patient was asked to call immediately. On day2, one hour after taking half dose of drug challenge, patient observed some reaction, made a call and went to emergency room Dr. Sardjito General Hospital, Yogyakarta. Physical examination revealed a rounded demarcated margin $10 \times 10$ $\mathrm{cm}^{2}$ erythematous itchy slight plaque. This eruption was preceded by sensations of itching three hours before. Methylprednisolone $8 \mathrm{mg}$ and cetirizine once daily for three days were given. 

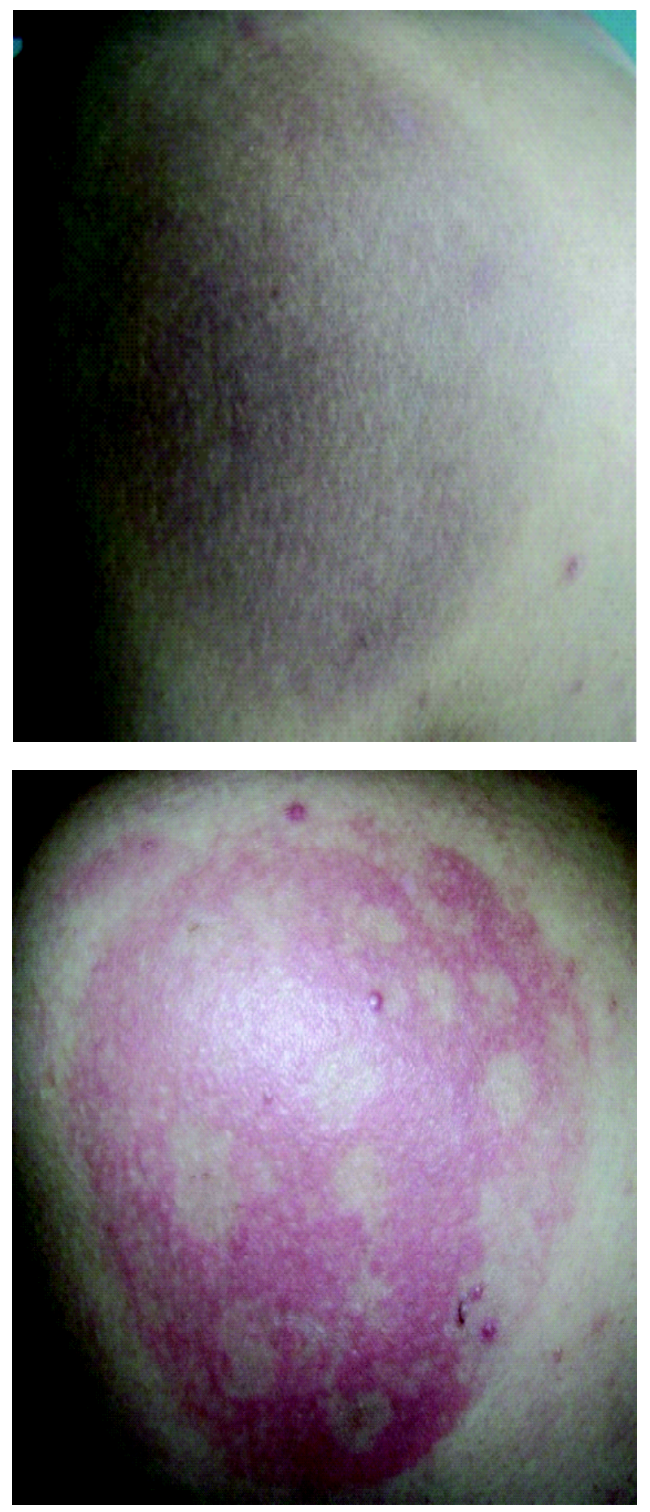

FIGURE 1. FDE lesion before and after systemic provocation test

\section{DISCUSSION}

Accurate identification of the agent inducing a patient's hypersensitivity reaction is important for future treatments to avoid labeling somebody as being allergic for life without good reason. ${ }^{20}$ The major results of study conducted by Messad et $a l .{ }^{21}$ reported that a true drug hypersensitivity represented in less than one quarter of the patients $(17.6 \%)$. This was of crucial importance for the therapeutic future of these patients. It is found that non-hypersensitive patients does not need to avoid these drugs in the future. The continuous search for alternatives leads to fear and often only less potent alternatives are found. ${ }^{20,22}$

The work-up of a suspected drug hypersensitivity includes a detailed clinical history, based on observation of the clinical signs, their time course and, eventually, their response to antiallergic treatment, physical examination followed by one or more of the following procedures: skin tests when available and validated, laboratory tests, and ultimately DPT. ${ }^{20,21}$

Patch testing with the suspected compound has been reported to be helpful in determining the cause of a CADR and in studying the pathophysiological mechanisms involved. ${ }^{20}$ The main advantages of DPT are that they can be done with no hospital surveillance because they induce only rarely adverse reactions and that any commercialized form of a drug can be used. ${ }^{23}$

In this case, patch test was performed with commercialized form of doxycycline in 30,40 , and $60 \%$ concentration both in petrolatum and distilled water. The first patch test were either negative or irrelevant. The patch test gave possible relevance to carbamazepin $10 \%$ without any prior exposure. This unexplained positive reaction should be informed to the patient that such reaction may be significant in the future. The second patch test with the alleged culprits was deemed negative despite the appearance of papule eritematous base at the site of application of doxycycline $60 \%$, because the papules lasted with pustule in day- 4 and day5. This appearance is most probably due to irritancy of the preparation caused by high concentration.

It is important to realize that a negative test does not exclude the responsibility of the drug being tested. ${ }^{22}$ There are several reasons for these negative results, especially when the test is performed with specially prepared materials rather than standard test patches. The drug may not 
have reached the immunocompetent cells in amounts sufficient to elicit a visible response, because its concentration was too low or its vehicle inappropriate or its degradation process and UV radiation. The CADRs may have been caused by a metabolite of the tested drug, by drug interactions, or by nonimmunologic toxic effects. Reactive metabolites, when available, may not penetrate the skin barrier, leading to false-negative results..$^{20,24}$

Skin tests and in vitro tests are always firstline investigations when drug hypersensitivity is suspected. Tests with negative cases or when skin tests can not be performed and the lymphocyte transformation test is not available or is negative, challenge is the only method to exclude allergy. The DPTs can reproduce the hypersensitivity reactions of the clinical episode, but they are in general milder and have a shorter duration. Although they are dangerous procedures and potentially life-threatening, these tests are important to confirm drug hypersensitivity, and therefore nonhypersensitive patients would not need to avoid the related drugs in the future if the result of the test was negative. ${ }^{21,24,25}$ The DPT is recommended to confirm drug hypersensitivity reactions by the European Network for Drug Allergy from the European Academy of Allergology and Clinical Immunology. The DPT should nevertheless be regarded as a serious and potentially dangerous procedure. It is important to document the patient's personal details, medical history and concomitant drug therapy and to have full resuscitation facilities available during the tests. However, outpatient provocations can be carried out with good results, when patients with a history of serious reactions are excluded. ${ }^{15}$ During the long follow-up period, only one serious reaction was seen, which could not be foreseen on the basis of patient history. ${ }^{21,24,25}$ Generally, the DPT with a suspected or alternative drug should not be performed on patients with severe comorbid illnesses (that is, underlying cardiac, hepatic, renal, or other diseases). Absolute contra- indications to rechallenge with medication include patients who have had severe life threatening reactions, such as vasculitis, the Stevens-Johnson syndrome, toxic epidermal necrolysis, drug reaction with eosinophilia and systemic symptoms, and organ involvement. Although very rare, these reactions, if reactivated, may not be controlled medically. ${ }^{21,24,25}$

Systemic provocation test is the gold standard in diagnosing FDE. Oral DPT in FDE seems safe even in children, if the patient suffered only single or a few lesions, but should not be attempted in patients who had generalized bullous reactions which may sometimes be difficult to distinguish from Stevens-Johnson syndrome. Testing with a sub-therapeutic initial dose, e.g. with $1 / 8$ of a tablet, that is increased every 12 to 24 hours up to a whole tablet, is a suitable method. A positive test result is a flareup reaction on a FDE lesion within 10-30 minutes up to $10-18$ hours. ${ }^{1,21,25}$ Lamintausta et $a l .{ }^{25}$ used one-quarter as initial dose in case of evident exanthema. The appropriate time for performing rechallenge has not been determined, although one to two months after the original eruption has been suggested. ${ }^{1} \mathrm{~A}$ physician performing DPT for drug hypersensitivity reactions has to know the needs considerable experience in order to be able to differentiate many reasons for false-negative and falsepositive test results. These reasons are numerous but can be evaluated and avoided in most cases. ${ }^{21}$

The discrepancy between the result of patch testing and oral DPT in this case could arise from several factors, namely the capacity of making reactive intermediate in the skin, and hyperpigmentasion with or without thickening of the patch test result, which make accurate reading of result difficult. ${ }^{21,24,25}$

\section{CONCLUSION}

In conclusion, this case report has succeeded to identify doxycycline as the causal 
agent of FDE with DPT under ambulatory surveillance.

\section{ACKNOWLEDGEMENTS}

We are grateful to Dr. Retno Danarti, SpKK who has helped in editing this paper.

\section{REFERENCES}

1. Ozkaya E. Fixed drug eruption: state of the art. J Dtsch Dermatol Ges 2008; 6(3): 181-8.

2. Korkij W, Soltani K. Fixed drug eruption: a brief review Arch Dermatol 1984; 120(4): 520-4.

3. Krahenbuhl-Melcher A, Schlienger R, Lampert M, Haschke M, Drewe J, Krahenbuhl S. Drug-related problems in hospitals: a review of the recent literature. Drug Saf 2007; 30(5):379-407.Patel RM, Marfatia YS. Clinical study of cutaneous drug eruption in 200 patients. Indian J Dermatol Venereol Leprol 2008; 74(4):430.

4. Lee AY. Fixed drug eruption incidence, recognition, and avoidance. Am J Clin Dermatol 2000; 1(5): 277-85.

5. Litt JZ. Litt's drug ruption reference manual. $11^{\text {th }}$ ed. London: Taylor \& Francis, 2005.

6. Mahboob A and Haroon TS. Drugs causing fixed eruptions: a study of 450 cases. Int J Dermatol 1998, 37(11):833-8.

7. Tavallaee M and Rad MM. Fixed drug eruption resulting from fluconazole use: a case report. J Med Case Rep 2009; 3:7368. Doi: 10.4076/17521947-3-7368.

8. Thien FCK. Drug hypersensitivity. Med J Aust 2006; 185(6): 333-8.

9. Mirakian R, Ewan PW, Durham SR, Youlten LJ, Dugué P, Friedmann PS, et al. BSACI guideline for the management of drug allergy. Clin Exp Allergy 2008; 39(1): 43-61.

10. Lammintausta $\mathrm{K}$, Kortekangas-Savolainen O. The usefulness of skin test to prove drug hypersensitivity. Br J Dermatol 2005; 152(5): 968-74.

11. Shear NH, Knowles SR, Shapiro L. Cutaneous reaction to drugs in Fitzpatrick's dermatology in general medicine. $7^{\text {th }}$ ed. New York: McGraw-Hill, 2008

12. Sweet RL, Schachter J, Landers DV, Ohm-Smith M, Robbie MO. Treatment of hospitalized patients with acute pelvic inflammatory disease: comparison of cefotetan plus doxycycline and ana doxycycline. Am J Obstet Gynecol 1988; 158 (3 Pt 2): 736-41.

13. Määttä M, Kari O, Tervahartiala T, Peltonen S, Kari M, Saari M, et al. Tear fluid levels of MMP-8 are elevated in ocular rosacea-treatment effect of oral doxycycline. Graefes Arch Clin Exp Ophthalmol 2006; 244 (8): 957-62.

14. Walker DH, Paddock CD, Dumler JS. Emerging and re-emerging tick-transmitted rickettsial and ehrlichial infections. Med Clin North Am 2008; 92 (6): 1345-61.

15. Bonnetblanc JM. Doxycycline. Ann Dermatol Venereol 2002; 129(6-\&):87482.

16. Gul U, Gonul M, Soylu S, Kaya I. Doxycyclineinduced fixed drug eruption. J Dermatolog Treat 2008; 19(2): 126-7.

17. Walfish AE, Sapadin AN. Fixed drug eruption due to doxycycline and metronidazole. Cutis 2002; 69(3):207-8.

18. Correia O, Delgadot L, Polonia J. Genital fixed drug eruption: cross-reactivity between doxycycline and minocycline. Clin Exp Dermatol 1999; 24(2):137.

19. Barbaud A. Drug patch testing in systemic cutaneous drug allergy. Toxicology 2005; 209(2): 209-16.

20. Messad D, Sahla H. Benahmed S, Godard P, Bousquet J, Demoly P. Drug provocation test in patiens with history suggesting an immediate drug hypersensitivity reaction. Ann Inter Med 2004; 140(12):1001-6.

21. Sasseville D. The role of skin testing in drug eruptions. Dermatology Rounds McGill University Health Care 2002; 1(1): 1-6.

22. Cravo M, Gonzalo M, Fiqueredo A. Fixed drug eruption to ceterizin with positive lesional patch test to thr three piperazine derivatives. Int $\mathrm{J}$ Dermatol 2007; 46(7):760-2.

23. Aberer W, Bircher A, Romano A, Blanca M, Campi $\mathrm{P}$, Fernandez J, et al. Drug provocation testing in the diagnosis of drug hypersensitivity reactions: general considerations. Allergy 2003; 58(9):854-63.

24. Lammintausta $\mathrm{K}$, Kortekangas-Savalainen O. Oral challenge in patien with suspected cutaneous adverse drug reactions: finding in 784 patients during a 25-year-period. Acta Derm Venereol 2005; 85(6): 491-6. 